\title{
FINANCIAL SECURITY OF FUNCTIONING OF THE BUSINESSES IN THE AGRICULTURAL SECTOR OF ECONOMY IN THE CONDITIONS OF CHANGES
}

\author{
Antokhov A. A., \\ d.e.s. assistant professor Chernivtsi National University of Yuri Fedkovich, Chernivtsi, Ukraine \\ ORCID ID: https://orcid.org/0000-0003-3887-9666
}

\author{
Antochova I. M., \\ c.e.s. assistant professor Chernivtsi National University of Yuri Fedkovich, Chernivtsi, Ukraine \\ ORCID ID: https://orcid.org/0000-0002-7766-3596
}

Byndiu $V$., c.e.s. assistant professor "Bukovynian University" Chernivtsi, Ukraine ORCID ID: https://orcid.org/0000-0003-2581-0117

Popel L., senior lecturer in P.H.E.I. "Bukovynian university", Chernivtsi, Ukraine ORCID ID: https://orcid.org/0000-0002-5813-5296

DOI: https://doi.org/10.31435/rsglobal_ijite/31052020/7066

\section{ARTICLE INFO}

Received 17 March 2020

Accepted 13 May 2020

Published 31 May 2020

\section{KEYWORDS}

agricultural sector, financial policy, financial security, financial resources, leasingfinancial state assistance, budgetary financing. \begin{abstract}
The problem of the importance of the financial security of business development in the agricultural sector of economy is covered in this article. The importance of inner and outer sources of financing during the organization of their practice has been determined. Special attention is payed towards the problematic questions of build-up of the capacities of financial resources, determination of the optimization of sources of their formation. The problematic questions of bank lending and the implication of the financial resources through the stock market are also covered below. Great attention is directed towards the importance of the state financial assistance for agricultural sector of economy development.
\end{abstract}

Citation: Antokhov A. A., Antochova I. M., Byndiu V., Popel L. (2020) Financial Security of Functioning of the Businesses in the Agricultural Sector of Economy in the Conditions of Changes. International Journal of Innovative Technologies in Economy. 2(29). doi: 10.31435/rsglobal_ijite/31052020/7066

Copyright: (C) 2020 Antokhov A. A., Antochova I. M., Byndiu V., Popel L. This is an open-access article distributed under the terms of the Creative Commons Attribution License (CC BY). The use, distribution or reproduction in other forums is permitted, provided the original author(s) or licensor are credited and that the original publication in this journal is cited, in accordance with accepted academic practice. No use, distribution or reproduction is permitted which does not comply with these terms.

Problem. The efficiency of businesses in agricultural sector of economy, for the most part, depends on how are they financially secured and their presence of financing sources. Unfortunately, most of the agricultural businesses require financial resources, due to the lack of their own resources when it comes to organizing one's activities. Hence why the objective need in the involvement of other sources appears.

Banking credits happen to be chosen the most, however, they are inaccessible for the most businesses of this sector due to the low level of their solvency and high (interest) rates for credit usage. In accordance to that, what has been said above, agricultural businesses are involving financial resources via direct investments, leasing, expanding, forward purchases of agricultural products, stock markets, etc. On top of that, the government with the help of the state regulations implements legislatively regulated rules on how subjects of agricultural business should act, and also provides individual branches 
of horticulture and stockbreeding with state help, which increases their financial resources. Nonetheless, long-term state strategy on the agricultural business development is unable to be truly solved due to the lack of state finances, their irregular providing and violations of payment period.

Analyses of latest researches and publications. The problems in the finance field of agricultural sector in economy has been researched by these well-known scientist: V. Ambrosov, V. Alexiychuk, L. Buriak, A. Borsh, M. Demyanenko, V. Mets, V. Oparin, P. Layko, S. Loyevska, O. Pavlovslka, A. Poderiohin, R. Slavyuk, P. Stetsiuk, O. Chaplihina, A. Chupis and others. Regardless of the high value of scientific researches, due to objective and subjective reasons and the influence of different circumstances on the activity of agricultural businesses, the question of their financial well-being and the determination of the priority directions and the effective usage of financial resources requires further deeper studying.

The formation of article objective and arguments regarded the relevancy of raised question. The development of the operating mechanism of financial security of businesses of agricultural sector of economy of Ukraine is a multi-sided obstacle which depends on tactical and strategic directions of country's agricultural policy, specifications of this branch: seasonal production; quite long production cycle; high need of credit resources; widely spread usage of rented land, specific rules of organizational and legal forms of property. The cons of financial resources have a negative effect on the manufacturing and propertied activity of agricultural businesses, leads to the decrease of further financing of their growth. For the time being, the problems of the financial security improvement and the improvement of formation mechanism and the usage of financial resources stays relevant for agricultural businesses.

Main part. Agriculture as a branch of material manufacturing has a list of features which leave mark on its functioning and financial well-being. Conducted reforms are aimed to bring changes in land business, privatization of objects of agroindustry complexes, new village property managing methods implementation which didn't reach expected results, as a result of an absence of functioning mechanism of advanced recreating main means; the increase of debit and credit indebtedness; reduction in production; lengthy periods of non-payments, undeveloped financial market, unfavourable tax laws and bank credit policies only worsened the deficiency of financial resources in businesses of agricultural sector of economy.

The establishment of functioning mechanism of financial security of agricultural enterprises is a multi-vectoral model which is dependant on range of factors and specific characteristics of given branch. By unravelling the essence of financial security of agricultural businesses it is advised to consider the specific features of this branch's functioning and their influence on financial activities. It should be noted that the features, such as seasonality, production cycle length, climatic influences, wide usage of rented lands, the specifics of different organisational and legal forms of housekeeping functioning, higher demand in financial resources, nonetheless credit resources. It is important to note, that all the features above are interconnected between each other.

Transformation actions in agricultural business are closely related to cardinal reforms regarding privatisation of agribusiness complex, village land relationship regulations, new market forms of business conducting development, etc. Even though the changeovers had positive outcomes, nonetheless, the given changes have been accompanied by the list of unsolved dilemmas: lack of functioning mechanism of expanding reproduction of main means (owned and lended ones); growth of credit and debit debts; non-payment crisis, adverse tax laws; agricultural products manufacturing shortage; severe deficiency of financial resources [3].

Worth noting, is that a unique influence on financial wellbeing is commenced by objective nature features of agricultural manufacturing, which influence the financial results of housekeeping in this branch by entangling with factors of organisational, economical and technological nature.

The specific feature of agricultural business activity is the usage of the land as the main mean of manufacturing, i.e., there are used 4 resources in rural businesses - main capital, working capital, live work and land, which makes up the bases of rural business. Herewith, the land, whilst staying in continuous rural turnover, needs financial reproduction on the expanded bases, in accordance to that, it requires from goods manufacturers investments. [2, p. 73].

The drastic influence on financial wellbeing of agricultural businesses is put on by grand rent payments, because more than $90 \%$ of agricultural territories is rented by agricultural businesses. 
The natural seasonality of agricultural manufacturing has also a strong influence on a financial activity of businesses, after all when the usage of means of manufacturing and workforce is uneven the monetary earning and incomes arrive unevenly throughout the year. This calls out for an increased need in implication of financial capital in the business process.

It should be considered, that all the features of agricultural sector of economy above have the direct influence on the specifics of forming and usage of its finances.

Defying the meaning of term "business financial security", it should be noted, that in wider understanding it generalizes the summary of measures and conditions that cause invariable business development by covering its expends with financial resources, depending on the size of the manufacturing and financial being [3, p.64]. On top of that, with a narrower understanding, the financial security - is the summary of certain forms, entanglement methods and the usage of financial resources. Having that, there should be noted conceptual basics of financial security, namely: [2, p.78]:

- Financing system - forming of monetary fonds to secure the agricultural activity;

- Optimal merger of different financial sources;

- Provision of effective financial resource usage;

- An Improvement of payment disciplines and provision of commencing payment operations in time;

- Wide usage of investing and innovation financial instruments.

The downside of financial resources in businesses of agricultural sector of economy has a negative effect on manufacturing and housekeeping activities, which is accompanied with a growth of debts, losses, income shortages and in the end by reducing financing with ones funds

Financial provision of agricultural sector subjects is made through the finance mechanism, that is the combination of financial forms and methods, tools and pressure points, which are used by agricultural proprietorships in accordance to regulatory and legal field.

The core of financial mechanism are financial resources of agricultural businesses, which are formed out of owed, own, involved and fund, which are not required to be turned back. Exactly financial resources play important role in their activities. At mean time they also provide:

- Running costs financing for businesses and continuous recreating;

- Tax obligations and obligations before other proprietor subjects and business employees;

- Stable development and business reputation, executing tactical and strategic goals;

- Stimulate positive income results, income level growth;

- Avoiding of financial risks via capital insurance;

- Social business development. [2, p.76].

The formation and usage of financial resources of agricultural enterprises is a process of forming monetary funds for financial security of ones' activity, execution of financial obligations before subjects of housekeeping and country. In the process of financial security the financial resources can be as an indicator of cost disproportion, nonetheless, losses, non-payments, deficiencies and aimless spenditure of money and other negative ocurances.

It should be noted that financial security of business of agricultural sector of economy moreor- less depends on organizational and legislative form of agricultural business proprietorship. According to Ukraine laws agricultural businesses are presented in such forms: business companies (stock companies, companies with limited liability), private enterprises, farmers businesses, agricultural manufacturing cooperatives, state enterprises and other formations. Every business formation has its own specialised way of capital forming.

Having that, the financial activity of agricultural manufacturers covers inner and foreign financial relationships. Their objective is to create a necessary financial base for food and raw plant and animal products manufacturing with a usage of structural manufacturing units of the unnecessary financial base. According to the demands of nowadays market economy the inner financial relationships provide the forming of the financial base from its own financing sources. Though, gathering of given resources in a major amount during the business activities is quite problematic.

External financial relationships are causing the forming of financial resources from outer sources through the banking credits, insurance pays whilst insuring crops, attracted funds through finance market, etc.

The objective of external financial relationships is to aid the functioning of agricultural manufacturers (with the means of granting credits, insuring harvests, involvement of funds through the 
financial market, etc.), despite of that, assisting their staturory activities, and with realization of products, which they made (provisions, raw materials, including processed ones) in accordance to modern market economy requirements.

Accordingly, the key basis of financial mechanism of agricultural businesses development are financial resources, which are taken out own, involved and irreversible sources. The features of financial security of functioning of agricultural businesses, which have been considered allow us to point out the main issue which they encounter the most - which is rational usage, accumulation and formation of financial resources in the process of business activity.

The specific uniqueness of own financial resources lies in that they are directly belong to the agricultural enterprise, whilst using them, the control over the activity does not disappear. The most important factor of motivation when using financial resources effectively - is the income from different activities and depreciation charges. The control over income is mainly in enterprises hands, after paying taxes, the income is used for the manufacturing improvements, property growth and solving social issues.

The governmental support of rural workers plays out an important role in financial providing of businesses of agricultural sector of economy. The main types of governmental support of rural products manufacturers and agricultural market are: budget lending to grain manufacturers; financial business support of agricultural complexes through the price reduction of credits and leasing payments compensations; deregulation of the Ukrainian market of rural products and bans of owner rights discrimination; monetary supporting newly implemented growth and processing techniques for plant and animal products.

Despite of that, the support of rural manufacturers, regarding of types and quantities of production they choose, can be given through: appropriation of subsidies per processed unit; partial monetary refunding per highly reproductive seeds of rural cultures; completion of state programs, aimed at increasing soil's fertility, battling with parasites and deiseases of rural plants and animals, doing business on heavily polluted territories.

Disregarding all the variety of programs and measure that have been conducted by state towards stimulation of agrarians the tools are one-time and frequently uncoordinated.

The ways of financial state support of rural manufacturers are adjusted according to taken by Ukraine responsibilities at keeping up with the EU standardised rules. Direct state subsidies and grants are aimed at realisation of viable investing and innovating projects. With these circumstances rural manufacturers have to use the latest technologies and innovations to prove that their activities are highly performable and how they are superior then their competitors when they get financially supported by state.

Needless to say, that an effective state support and stimulations in rural business contribute towards stimulation of rural business, especially agricultural sector of country's economy, it will allow to solve the food (commissary) issue, it will provide the market with high quality commissary goods and raw resources. With these new possibilities arise to form and to function competitive agricultural market which will cause for a much wider potential realisation of domestic rural manufacturers both on domestic and external markets.

The elevation of agriculture to a more advanced level is possible if an effective innovative activity, which the state policy will promote, which will provide the realization of quality budget financing and stimulation. State's job is to balance interest of all its people, whilst supporting agrarians' activity, especially rural manufacturers, rural products consumers and country at the same time. Monetary support of innovative processes in agricultural sphere is capable of providing a decent level of rentability, to stimulate manufacture of plants and animal products with a purpose of solving commissary safety, to create stable economical state in this branch.

The implementation of program and goal technology of budgeting is effective, because in conditions of budget deficit they financial resources are concentrated on problematic priority problems of agricultural economy. If it comes to budget financing of targeted programs (from state, regional or regional budgets), then when choosing the effective variant of financing the targeted program these criteria should be acknowledged: priority of program goals; financing form; reason behind chosen amount of money; performance (expected economical, ecological, social or other type of effect); financial effectiveness.

So, budget support of agricultural sphere support has a very important meaning and should effectively co-exist with other ways of state regulation. Its main task should be stimulating nature of payments which are tied to implementation of innovating mechanisms. On top of that all processes of 
financial support of rural business should go through governmental check-ups on the principal of preventing, which will cause the increase of its effectiveness level.

Nowadays the most anticipated moment for rural manufacturers, who are implementing innovative researches into their activities, is getting a financial assistance in time, because implementing innovations into the rural business has specific features coming from specifics of agricultural manufacturing. Budget financing of plant growing is characterised by payments per hectare with an intention to support manufacturers, which requires a significant amount of investments which also has a lengthy period of payback (planting trees in gardens, grape vines, hops, cultivation of unprofitable plants, which are socially necessary, etc.) Dating in planting branch is accomplished in three ways: winter plants, grains and other.

The importance of favourable terms of rural workers is that it makes up $50 \%$ of all rural businesses and in some sectors of rural manufacture (for example animal husbandry) the maintenance of positive economical outcomes mostly depends on a presence of extra favourable terms.

State regulations of agricultural development in foreign countries is one of the anchors that prevents the implementations of agricultural and financial policies in rural businesses. In the systems of state regulations of USA and Eu West economies it led up to that the manufacturers of rural products are in the separate group which gets extra payments from the government, not only for the innovation development, for the most part solely for their status. The reasoning behind higher attention towards agricultural sector of economy is explained by specifics of rural manufacturing.

Main ways of state assistance in development of rural manufacturing of leading countries are the: support of manufacturing and increase of competitiveness of agricultural subjects in the way of manufacturing ecologically clean production; support of small manufacturers, beginner proprietors, family farms and cooperative associations; land preservation and rational usage of rural goods; creating prices and support of rural production; development of agricultural science and implementation of eco-safe technologies whilst producing rural products, taking care of animals and systems of taking care of soil and others [5, p.86].

Special meaning behind means of state support and development in EU countries has budget financing. Near $40 \%$ of budget goes to subsidies in EU countries. From the general sum of compensational payments $2 / 3$ are made out of payments from land calculations and per animal unit. With an intention to stimulate farmers to seek out newer methods of gaining income, wider spread also got payments of subsidies to support rural territories [5, p.86].

So, the experience of country with the developed economy means that about the diversity of form of state stimulation of activities in rural sector of economy and its important role in in providing of market balance and increasing the possibilities of economical choice for rural manufacturers. This experience is especially relevant for Ukraine. In spite of positive movements in state policies which are targeted agricultural sphere, researches of its state have shown that manufacturers feel the unfinished process of institution and legislative base their activity regulation forming, investment and innovation climate, informational and consulting providing of activities for the manufacturers, in part of providing certain information about market prices and way of getting state assistance.

Certainly, every source of financial security of development of businesses of agricultural sector of economy has especially important role, which means that agricultural businesses have to help in growth of financial resources, optimize their contents and structure, make their control effective at every stage of manufacturing, detect reserves of financial growth of resources, provide income and avoid losses, finds ways of improving the financial state.

For the effective reproduction and maximum multiplication of financial resources and clearly following the criteria. Ones capital should be aimed towards formation of material and technical bases and for the uninterrupted manufacturing, i.e. into main means, working and productive cattle, aged plantations and working capital. In the end the received income will multiply one's capital.

In turn, the borrowed long-term capital should be aimed towards innovation investments, building capital and short-termed should be turned into working capital. The income got from actives should be sent to banks to cover the usage of their resources and for furthermore growth of capital.

In the process of banking crediting rural businesses can get risk which are tied to the growth of the interest rate in active contracts or late receiving of credit sum. One of the ways to neutralize financial risks is hedging, which can optimize one's strategy of controlling the financial risks, foresees the shift in the conditions and the ability to decline in case of lose situation [4, p.48]. 
Rural businesses as the result of their specifics can determine periods and capacities of the credit resources and can conclude a contract and fixate the size of the credit payment. This is quite positive, because it allows to predict and balance future money income, predict incomes and costs of agricultural business. The mechanism of hedging with the help of forward contracts for percentage rates can have perspective with banking crediting and operations on the financial Ukraine market.

Involved capital has short term of usage and also an unstable character, so for its account it is reasonable to finance cost by the debit debt, current financial investments, etc. In this case the income should be directed towards coverage of costs, which are not part of gross costs and are made from pure income.

In this way only the effective mechanism of financial security of the activities of agricultural sphere will allow to raise this branch on the new level of development. The well-established mechanism of agricultural enterprises financing will give an opportunity to increases the amount of manufacturing, it will have a directly in proportion impact on the expended reproduction. The mechanism of financing agricultural businesses will give the possibility to increase the capacities of manufacturing, proportionately will impact on the recreation. The state is supposed to balance interests of the whole society, provide enough of the level of rentability, solve food security of the state, create stable economical situation in given branch, whilst supporting the development of agricultural sector.

\section{REFERENCES}

1. Anastasova K. "Mechanism of financial security of agricultural enterprises" / Anastasova K. // "Junior scientist” - № 1.1 (41.1) - jan. 2017. Retrieved from http://molodyvcheny.in.ua/files/journal/2017/1/178.pdf

2. Bilochenko A. "The state of perspectives of attracting of financial resources into Agricultural Industry Complex of Ukraine" / Economy of AIC. - 2017. - №6. - P. $72-76$

3. Gudz O. "Providing of agricultural enterprises with financial resources: theory, methodology, practice: Gudz O. - Kyiv, 2017 - 39 p.

4. State support of agricultural sector in 2017. Retrieved from http://www.auu.org.ua/uk/publications/web/206/ 